\title{
Narratives of Change and Theorisations on Continuity: the Duality of the Concept of Emerging Power in International Relations
}

\author{
Lucas de Oliveira Paes* \\ André Moreira Cunha** \\ Pedro Cezar Dutra Fonseca ${ }^{* \star *}$
}

\begin{abstract}
This essay aims to discuss the appropriation of the concept of emerging power to the field of international relations, the theoretical impact it inflicts on the discipline, and the duality of its formation as a theoretical category. The adjective emerging has been appropriated into the vocabulary of international relations, but such lexical novelty comprises a debate with earlier theorisations on intermediate states. It is argued that this dialogue between the transience in the narratives of change, brought up by the qualifier emerging powers, and the stasis from the theoretical accumulation on the condition from which it breaks through is a constitutive foundation for the concept as an analytical device for international relations.
\end{abstract}

Keywords: Emerging Powers; Emerging Markets; Intermediate States; Middle Powers; Regional Powers; Semi-Periphery.

\section{Introduction}

This essay aims to discuss the appropriation of the concept of emerging power by the field of international relations and the duality between change and continuity in its formation as a theoretical category within the discipline. The term emerging or rising power has been used to describe countries whose influence in international relations is expected to be currently expanding. The term is not new in the field, but has gained special attention recently as a particular subject of study, even receiving specific institutional initiatives

\footnotetext{
* University of Denver, Denver-CO, United States; lucas.opaes@gmail.com.

** Federal University of Rio Grande do Sul, Porto Alegre-RS, Brazil; andre.cunha@ufrgs.br.

*** Federal University of Rio Grande do Sul, Porto Alegre-RS, Brazil; pedro.fonseca@ufrgs.br.
} 
in relevant universities. ${ }^{1}$ Despite manifold robust appreciations of its theoretical delimitation, the concept still has to deal with a lack of consensus concerning its connotative and denotative spectrum (Hurrell 2006, 2013; Narlikar 2010; Schwengel 2008). This work intends to contribute to this debate by analysing the meanings underlying the narratives that brought the term to international relations literature and the theoretical challenge the concept inflicts upon theory in such appropriation. By tracing this constitutive formation, we expect to shed light on the analytical possibilities the term emerging power has as a device of international relations theory.

The current meaning of the term emerging power derives from the 'stretching' of the adjective emerging, beyond the connotative range of the terminology of emerging market, which has 'travelled' to denote those rising players in the international order. ${ }^{2}$ This category regards transformations of world economy and politics in the course of the twenty-first century by semantically framing its historical particularity. The concept, then, has been widely spread in both academic literature and political practice to refer to international relations phenomena of a particular kind: the empowerment of states that generally symbolise rupture with the status quo. However, at the same time, by being incorporated into the international relations' vocabulary, such lexical and historical novelty comprises an established debate within the field: theoretical appraisals on intermediate states, how stable this condition is, and how to rise from it.

In the terms of Koselleck (2004), the concept of emerging power frames a historical process in its own time and engenders a diachronic contention with the accumulated interpretations of a longer past established within international relations theory through other concepts. The concepts of semi-periphery, middle powers, and regional powers were formulated in the discipline to denote the political consequences of the intermediate position of certain states in the international system, those which are too big to play no role in the balance of forces, but too small to keep the forces in balance by themselves.' However, in order to make sense of the intermediate states of international relations, these categories theorised on positions, their determinants, and their consequences, reflecting a static account of the international system. Opposing continuity and stasis, the narratives about emerging powers posit themselves as portraying a rupture from the intermediate state's position, as its asymmetrical counter-concept (Kosselleck 2004: 155-91). As such, this content manifested by the first cannot be detached from the latter, which it intends to negate. Hence, their dialogue reveals its constitutive duality.

The theoretical accumulation on intermediate states stands out as the rules of usage within the field by which the category is appropriated. In this sense, the consolidated understanding on intermediate states in international relations theory, carried out by the concepts of semi-periphery, middle powers, and regional powers, is part of properly understanding the theoretical role of the term emerging power. These contrasting categories allow one to reason about the concept beyond a theory of its own historical momentum, a narrative of an epochal change, by facing the theoretical determination that its pragmatics challenges in order to constitute itself as a concept within the discipline.

To comprehend the formation of the concept and its explanatory contribution as an analytical device of international relations, this article is structured to analyse its inher- 
ent duality between disruption and stasis. Firstly, it describes the appropriation of the lexicon for emerging - from the adjective emerging markets in the financial literature until its fusion with the category of rising/emerging power - as a manifestation of the historical transformation that comprises the increase in its use in the academic vocabulary of international relations. The work proceeds, then, to analyse the duality in the semantic patterns brought by the concept emerging power. In this sense, the second section discusses the very depiction of transience in the term as opening a dialogue with conceptions of continuity. The third section contrasts the latter with established categories of international relations theory regarding phenomena that are the opposite face of its same kind as a means to complete its constitutive dialogue with endowed knowledge in the discipline. For instance, this section appraises how the theorisations of the concepts of semi-periphery, middle powers, and regional powers outline the determination of the position from which the emerging powers ultimately break through. Finally, the concluding remarks engage in a comprehensive synthesis of this process, stating the duality comprising the concept and how it better allocates its theoretical place in the discipline.

\section{The appropriation of the lexicon for emerging by the field of international relations}

The post-Cold War world has raised an ongoing discussion on the distribution of power in the international system. Much of the contemporary literature of international relations has focused on understanding the challenges to the preponderance of the United States, hegemony, or unipolarity (Khanna 2008; Layne 2009, 2012; Ilkenberry et al 2011; Buzan 2011). Even though there is a high level of power concentration in restricted poles, the redesign of economic relations has particularly raised the discussion of the increased participation of peripheral spaces in world production and economic flows during this new phase. This shift has given relevance to interpretive efforts on the theoretical characterisation of those states that have been playing a greater role in the international system, even of those most distant to the reality of a hegemonic transition. Unlike as theories of war and change predict, the focus is now on the enhanced influence of mid-level actors instead of the great powers' politics of systemic change.

Within this context, the debate on conceptual alternatives for the denotation of these new actors arises (Hurrell et al 2000; Jordaan 2003; Cooper, Antikiewicz and Shaw 2007; Schwengel 2008; Nolte 2010; Schenoni 2012; Hurrell 2013; Cooper and Flemes 2013; Brütsch and Papa 2013). Underlying the dispute among established categories of international relations theory - i.e. middle powers, regional powers, semi-periphery - an expansion of the lexicon for emerging has been observed, (in expressions such as emerging countries, emerging powers, emerging markets, and a profusion of combinations of 'emerging' plus nouns) as a qualifier of those beneficiaries and/or entrepreneurs of the political and economic transformations in process. However, the debate on the term's denotative and, particularly, connotative spectrum remains largely open in the literature, hindering its treatment as a conceptual category. Thus, in order to reason its formation, this section analyses the semantic transformations undergone by the category in its appropriation by 
international relations and outlines the historical process in world economy and international politics that it is narrating.

Genealogically, the predicate emerging, although already present in the vocabulary of international relations, has been taken in its contemporary mood from a different field, that of the literature on financial markets, providing an equally different semantic context to the term. The connotative changes undergone by the meaning of the term emerging as a reference to international relations phenomena describe a process of 'conceptual travelling' and 'conceptual stretching' in the sense originally proposed by Sartori (1970). The notion of 'conceptual stretching' is used by the author to indicate the distortion a concept undergoes in its over-extension, ${ }^{4}$ namely its reference to cases that put their constitutive attributes in check. The denotation of cases confronting the term's original connotative borders is what Sartori calls 'conceptual travelling'. The present work observes that the 'travelling' and 'stretching' of the lexical field emerging, from the term of emerging market to the new meanings attached to the term emerging power, are constitutive elements of its appropriation by the study of international relations. It is argued that the appropriated category does not suffer from an over-extension, but requires additional effort to understand its place in the new theoretical context in which it is operating. Thus, this study is built upon the narratives that conducted this semantic transformation and, consequentially, promoted its dissemination as a qualifier of international relations phenomena.

This movement of the lexicon for emerging was initiated as a description of the subject of emerging markets in financial literature, referring to countries then newly integrated to the conditions of financial globalisation in the late twentieth century. Its initial environment was the scheme of the refinancing of developing countries' elevated debt stocks since the mid-1980s. The creation of the term emerging markets is attributed to Antoine Van Agtamael, former president of IFC (International Finance Corporation), the financial arm of the World Bank. He coined the term in order to reframe those countries in the financial markets risk classifications and to resume the flow of private capital to recycle their debt stocks. This classification replaced the former Third World funds in order to give greater credibility to these borrowers once they adopted the adjustment policies set by international financial institutions. In effect, what was being developed was a new category of financial assets that would gain prominence since the release of Brady Bonds (Levi 2009; Pilbeam 2013). However, this distinctive qualification of some Third World countries as emerging markets would later reveal a new semantic opposition that constituted the emerging powers. In the 1990s, the emerging market bonds became important fixed income components of various assets (Levi 2009; Pilbeam 2013).

This process gave rise to a large specific literature on the subject and, in consequence of its operational role, its first delimitative classifications. Solnik (1991) offers one of the pioneer boundaries to the term, acknowledging the original IFC classification, as a country that matches a positive evolution of per capita income with the adoption of adjustment measures. Pereiro (2002) and Harvey (1995a; 1995b) offer a more comprehensive list of attributes that would add to the adjustments and economic growth, indicators of the integration of these economies to international financial capitalism. In the IMF and World Bank's framework, over the 1990s, the category emerging markets is considered 
interchangeable with developing countries. This merger, however, has not received a delimiting systematisation; it has only been the identification of these geographic areas with new expanding economic opportunities. Emerging markets and developing countries are all those economies that are not the advanced ones, measured by the level of per capita income (World Bank 2013; International Monetary Fund 2015). The originally distinctive term of emerging markets turns itself into an operational term for the identification of a universal rest.

However, these new emerging markets found a new role in the international economy in the beginning of this century (Kose 2008). On the financial side, the difference in interest rates offered by some of these markets' currencies in relation to the dollar and other convertible currencies directed a large inflow of capital to them, mostly related to carry trade operations ${ }^{5}$ (Levi 2009; Pilbeam 2013). At the same time, there was a reorganisation of trade and production chains on the real side of the international economy. Since then, emerging markets have registered continued surpluses in their current accounts, driven by the performance of another 'emergent' factor, the rising industrial production of East Asia.

This briefly summarised process was already underway when Goldman Sachs first highlighted, among the many emerging economies, those that would play a central role in the future of the world economy: Brazil, Russia, India, and China (O'Neill 2001; 2003; 2005 ; 2007). Whereas the works of Goldman Sachs compose an empirical and operational literature, intended to help financial market agents, they reveal two important aspects of the content carried in the appropriation of this new meaning of the predicate emerging by the international relations literature. First, these works specify among the 'emerging world' a group of countries whose growth path could constitute a long-term movement towards the centre of the international economy. Second, the work argues that such a promise should allow their proper inclusion in international financial governance spheres, in particular through the G-7 expansion. Hence, this body of work casts a different view, within the financial literature, on these actors whose prominence was confirmed over the first decade of this century, and has outranged the scope of the financial market in the same way that the the meanings carried through the adjective emerging have overflowed that literature.

\section{The duality in the narratives of change comprising the concept of emerging power}

The twenty-first century has witnessed the spread of the qualifier emerging or rising employed with political referents, either by scholars or by diplomats, which carried these historical transformations into a vernacular legacy to be explored in the discipline of international relations. In this discipline, the term emerging power conflates past and present, becoming interchangeable with rising powers, both covalent to describing a renewed feature of the field, the novel role of the former emerging markets in the world economy and politics. The term that once described power transition among great powers ${ }^{6}$ now sheds light on phenomena of a different kind: the enhanced influence of the former Third 
World or the Global South. Therefore, the concept comprises wider dimensions of change that have to be commensurate.

In order to quantitatively gauge the bulk of the term's dissemination, the frequency of reference to the term in recent years was appraised, firstly in several academic databases ${ }^{7}$ and, then, narrowing the search for journals in JSTOR's sector of international relations and area studies. Figure 1 shows the growth rate average of references to this term during the process described earlier. It illustrates the expansion of the term emerging/rising power in academic production during this century, despite a smaller absolute relevance in comparison with the category of emerging markets. Furthermore, by narrowing the results only to journals in the section international relations and area studies at JSTOR, Figure 2 shows that the terms emerging/rising power gain absolute relevance, besides an increased trend of expansion until soon after the 2008's economic crisis. Alone, these figures support the perception that the nominalisations emerging/rising power have been the ones particularly appropriated by international relations vernacular.

Figure 1: Growth rate average of references in academic journals.

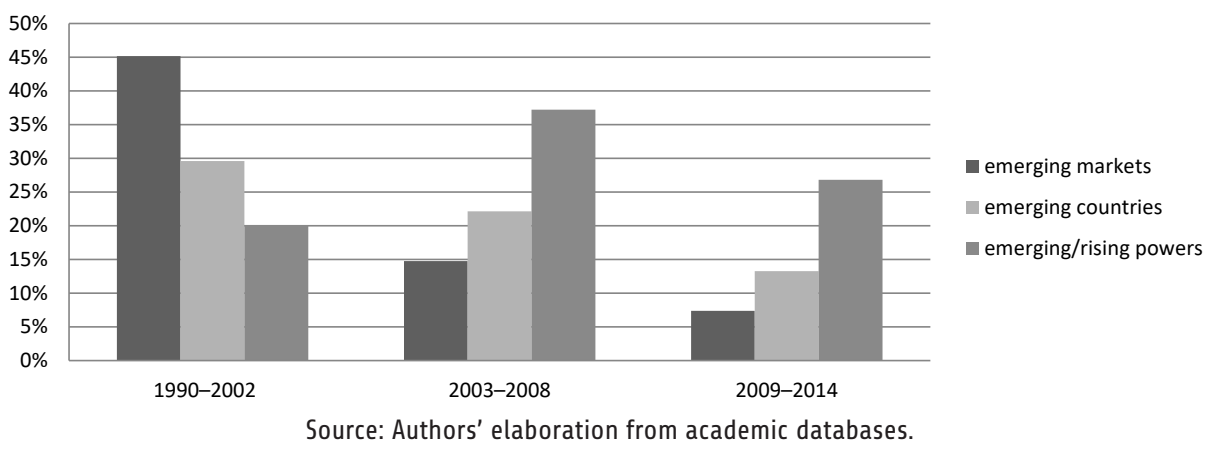

Figure 2: Frequency of references in JSTOR international relations and area studies - full text.

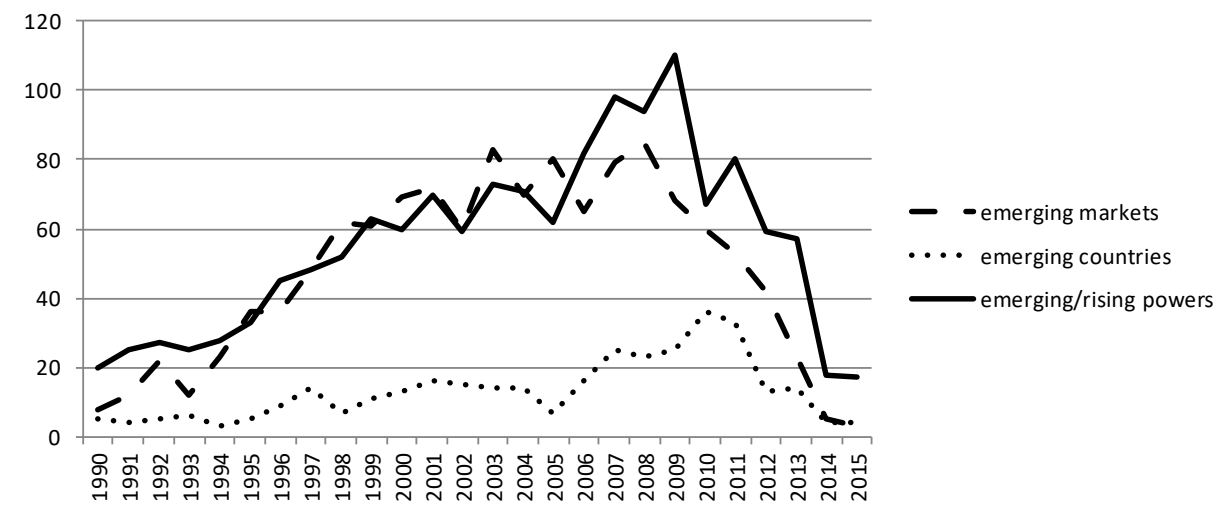

Source: Authors' elaboration from academic databases. 
Moreover, if contrasted with some simple figures from the world economy, this movement reveals an interesting correlation. Figures 3 and 4 display, respectively, the emerging markets' share of the world's income and their GDP annual growth. The expansion in the use of the overall adjectives seems to follow an expansion of emerging markets' economic performance and relevance, after a short interpretational lag. From that, it is reasonable to suggest that the appropriation of the term by the discipline and the expansion in its use may reflect a necessity to make sense of material and distributive transformations happening in international affairs. If we pay attention to the referents associated specially with the term emerging/rising powers, as shown in Figure 5, this perception can be reinforced. As emerging markets gain real space in the world economy, their empirical referents also become predominantly those of the qualifiers emerging/rising powers. The novel role of what were previously called emerging markets is told as a story of emerging powers and, thus, the very diffusion of the latter seems to be related to a transformation in the analytical perception of the first.

Figure 3: Emerging markets' and developing economies' share of world income, PPP (\%).

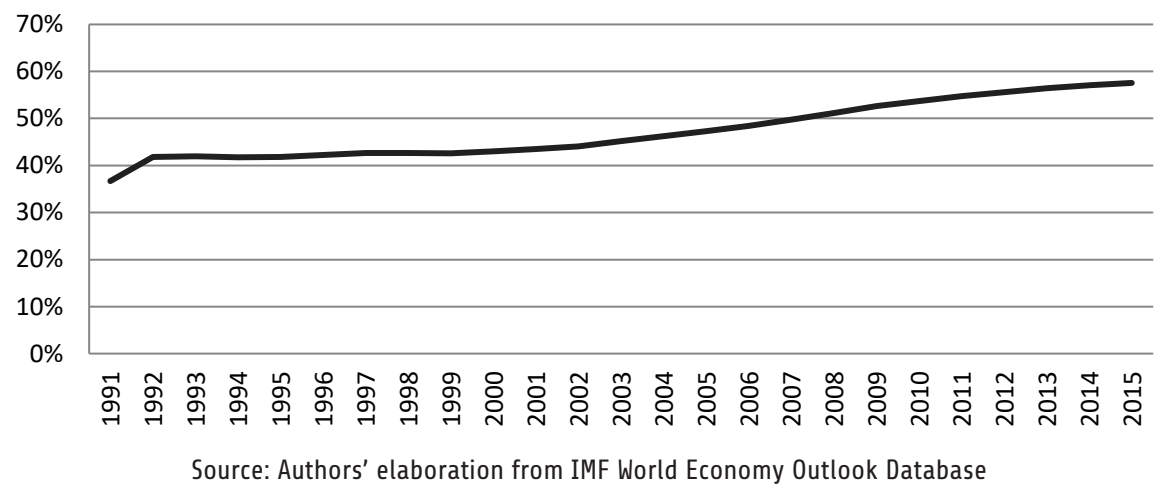

Figure 4: Emerging markets' and developing economies' gross domestic product growth, constant prices (\%).

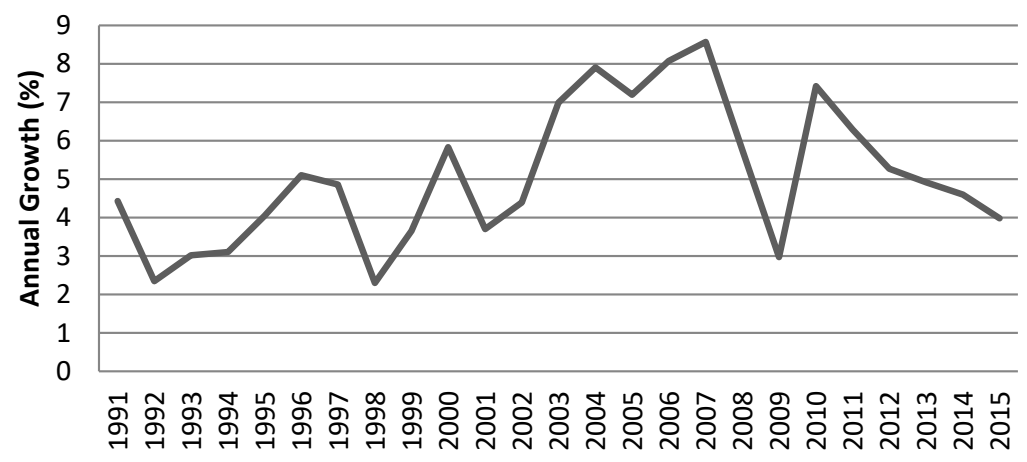

Source: Authors' elaboration from IMF World Economy Outlook Database. 
Figure 5: Compositions of empirical referents to the qualifier emerging power in JSTOR international relations and area studies.

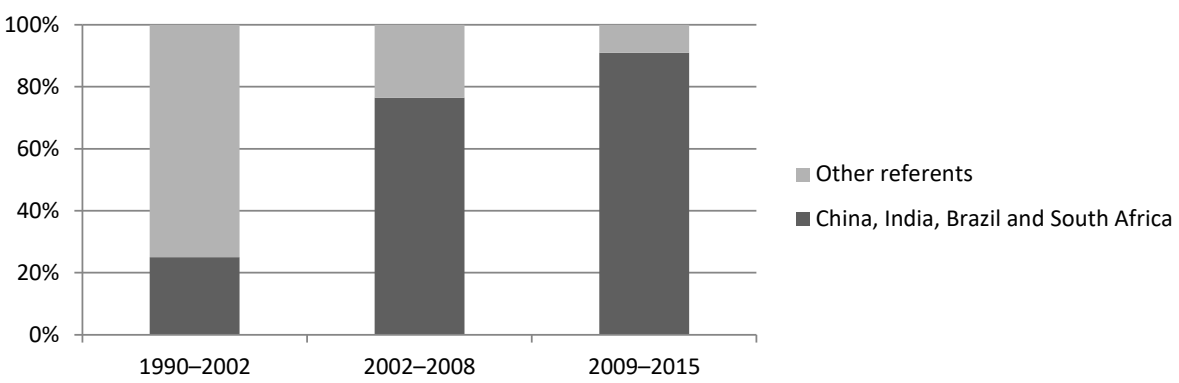

Source: Authors' elaboration from academic database.

In order to address the qualitative transformations in the term emerging within the discipline, the guiding narratives in the use of the terms emerging market, emerging countries, emerging power, and rising power have been studied. The semantic patterns in works that referentially used that term in relevant journals of the studied databases ${ }^{8}$ have been analysed. Both quantitative and qualitative analyses suggest the existence of a clear segmentation in the employment of the adjective emerging. The narratives attributed to emerging markets maintain their original dialogue with the operational classification of financial literature. The nominalisations emerging country, emerging power, and rising power, in turn, seem to depict the structural changes perceived in international relations in the course of recent decades. In general, the authors associate emerging with the phenomena of influence, material capacities, political activism, hegemony, and dominance, all of which relate to manifold dimensions of might. Thus, power is the quality that emerges from this literature, conveying the terms rising or emerging power to qualify it within this lexical range appropriated by international relations. Therefore, the adjective emerging has 'stretched' its connotative range according to changes within the reality of its referents.

The study of the contents underlying the 'stretching' of the concept, derived from its 'travelling', is perceived as a necessary first step to its framing as an analytical device in the field. Concepts as theoretical tools are logical constructs with the purpose of defining the constitution of a phenomenon, the particularity it tries to delimitate amidst generality (Sartori 1970: 1033-6; Goertz 2006: 5). Thus, its boundaries would have to be defined within the framework of a theoretical appraisal of the reality within the discipline (Sartori 1970; Goertz 2006: 235-7). However, a relevant part of the literature on concepts stresses the importance of strong connections between the technical language and the established use in the field in which the term operates (Rosch and Mervis 1975; Lakoff 1990; Collier and Mahon 1993: 853; Gerring 2001: 40). Koselleck (2004) goes beyond this and advocates for the dual character of concepts, both as a positive semantic fact and as a container of a historical process. This duality is particularly relevant to the process analysed here. The trajectory of the term emerging power seems to be semantically depicting a historical transformation. Hence, the constitutive dynamic hitherto described comprises a seman- 
tic momentum: as these narratives gave sense to the rising power of some actors, they delineated a set of connotative dimensions that built themselves in the identity of this phenomenon.

The analysed narratives of emergence consider the main attributes associated with the historical process of the emerging powers. In the literature studied, ${ }^{9}$ the most ubiquitous aspect identified in such a dynamic is the forecast or assumption that emerging powers will sustain a continuous economic growth and have long-term greater economic relevance, which would reinforce a greater influence in the international order (Andreasson 2001; Cooper, Antikiewicz and Shaw 2007; Macfarlane 2006; Claudín 2011; Sharma 2012; Stephen 2014; Chin 2014). In addition, the literature primarily qualifies the behaviour of the emerging powers through their claim for space in global governance, discussing whether their strategies have a reformist or revisionist character (Hurrell 2006; Tammem 2006; Cooper Antikiewicz and Shaw 2007; Ikenberry 2008; 2011; Beeson and Bell 2009; Mattoo and Subramanian 2009; Casteñeda 2010; Patrick 2010; Barros-Platiau 2010; Chin 2010; Schirm 2010; Desai and Vreeland 2011; Gray and Murphy 2013; Niu 2013; Golub 2013; Vanaik 2013; Weinlich 2013; Flemes 2013; Stephen 2014; Cooper and Farooq 2015). This quest for recognition has often been associated with the historical identity of not belonging to the status quo order regarding the ties of these countries to the Third World movement and to the idea of Global South (Burirty 2008; Palat 2008; Callahan 2008; Kang 2007; Stuenkel 2010; Nel 2010; Santos 2011; Hurrel and Segupta 2012; Narlikar 2013; Hurrell 2013). The ideological foundation or identity underpinning this behaviour is regarded in the literature as their trajectory of not belonging to the hegemonic order. At the same time, a regional scope is often attributed to these players, and regional dynamics are seen as the Gordian knot of their rise, either enhancing or undermining it (Waltz 1993; Hurrell 2006; Whitaker 2010; Flemes 2010; Buzan 2011; Burges 2013; Schenoni 2012).

Thus, the observation of gains in the redistribution of world economic flows in recent years seems to be the material base of this shift in the institutional and regional activism of the so-called emerging powers in the international order. Even after the more recently contracted expectation on further economic expansion of these countries, the relation between political behaviour and material redistribution of power to the Global South still governs the agenda in the literature (Sharma 2012; Brütsch and Papa 2013; Stephen 2014). For instance, Chin (2014) advocates the New Development Bank initiative of BRICS as the utmost symbol of this enterprise on reviewing international order to facilitate their development. Therefore, the literature outlines these four dimensions of the narratives driving the lexicon for emerging to international relations:

- perspective of relevant economic growth in the near future and a greater share of world economic flows;

- claim for greater recognition in global governance, whether through reformist or revisionist strategies;

- historical identity of not belonging to the status quo order;

- regional military or economic primacy. 
In this sense, the emerging power semantic momentum comprises narratives describing change set through the ambition of reform or revision of the international order, associated with an identity of non-belonging to the status quo of that order. At same time, the transience in these narratives is perceived in the relevance attributed to the perspective of the progressive acquisition of material conditions to support this empowerment. However, the persistence of the conundrum encompassing the redistributive politics in international arenas, the ideational dispute underlying that, and the material substrate of this process are here conceived as the semantic content conveyed to the discipline through the pragmatics of the concept.

The analyses of the semantic transformations within the term emerging in its appropriation by international relations sought to contribute to its analytical framing, systematising general aspects of the momentum that gave rise to its current meanings. However, as Gerring (2001: 53-4) ponders, the pragmatics in general language, per se, do not provide the conceptual validity, but a terminological spectrum that can be embedded in a specific technical language. Incorporation of the concept to international relations demands expanding the 'state of the art' expressed in its use and specifying the rules of usage governing it within the discipline. In other words, recognising Wittgenstein's allegory (2009: 38 ), once the 'nodes of the network of similarities' in the concept's use are concatenated, the task of defining its theoretical terms arises. The very sense that the term conveys a transient depiction of recent history into a semantic conception of change in international relations contends a veiled debate with the established understanding of how this phenomenon has not happened before. Thus, it is argued that each exposed dimension deserves its own study, incorporating a literature review and an intellectual reflection on its role in this new theoretical context.

\section{Conceptions of rising from the stasis of the approaches to the intermediate states in international relations theory}

The field of international relations was envisaged to comprehend interactions among system-determining states, the centre, or the great powers (Keohane 1969). Nevertheless, the globalisation of industrial and financial capitalism since the late twentieth century has given room to other players who do not determine systemic order, but whose integration in world dynamics would not allow this taxonomical gap anymore (Lima 1990: 7). A specific object of study has been recognised: a group of countries which 'are different from Great World Powers, but could not be confused with the mass of small countries ${ }^{10}$ (Sennes 2003: 17). This theoretical approach to intermediate states has been developed into three categories: semi-periphery, middle powers, and regional power. All these three attribute distinct substances to this position. To address these categories as the pragmatics underlying the theory on the rise of intermediate states, this essay investigates how each position is conceived and how the rupture with this is perceived in the literature.

Firstly, the concept of semi-periphery has its inception in the reinterpretation of the dualistic stratification 'centre and periphery', from ECLAC, ${ }^{11}$ by Braudel (1985) and Wallerstein (1974). A common ground for these authors is the interpretation that capi- 
talism has a 'texture' of the same kind in the microcosm of social domination and in the macrocosm of relations among states, areas, and populations (Braudel 1985: 67-9). The international system is perceived as a World-System, ${ }^{12}$ functionally and geographically stratified by the concentration of capital. Beyond this conception, it was Arrighi (1998: 137-253) who ascertained the theoretical determinants of the semi-periphery. For him, this group of states is stuck to its development illusion to the extent that their provision of revenue advantages to capital ultimately reduces their cost advantages. In other words, it is possible to understand the semi-periphery as a class of highly integrated players in the system, but whose interactions are subject to a structural constraint of resources.

The semi-periphery is, therefore, a rigid position understood as part of the process of systemic reproduction instead of its transformation. Still, Arrighi (1994; 1998) and Wallerstein (1976) discuss an exceptionally disruptive condition that allows a state to rise from within this position. This situation is the building up of sustained surpluses with the whole system. So, by maintaining advantages of cost to capital in relation to the centre and of revenue in relation to the periphery and semi-periphery, a state encloses a virtuous combination that, maintained in the long run, would symptomatically perform a trajectory towards the centre. However, the sustainability of such a path is dependent upon its ability to retain capital and, therefore, retain the innovation within its jurisdiction. Thus, the cases of emergency presented by Arrighi ${ }^{13}$ have their determinants mostly deriving from a change in the economic activities within the country, and consequently, in its insertion in the systemic accumulation process.

The literature on middle powers extracts the substance of this category from the behavioural rationale of the intermediate position. Keohane (1969) has been one of the subject's pioneer analysers, organising states according to the degree of influence they play in the international system. Middle powers are those states which have influence in international affairs through alliances and multilateral coalitions: the system-affecting states (Keohane 1969: 295). Lima (1990: 10-1) dilutes this segmentation in a continuum between autonomy and vulnerability, where middle powers are players that present the two similar doses, depending on the context of interaction. In this sense, given its positional limitations, the authors associate rise with strategies seeking greater influence in the international order. Coalition building and leadership strategies in international regimes are seen as the prime way to effectively impact international order and the constitutive attitudes of middlepowermanship (Holmes 1965; Cox 1989). Hurrell and Fawcett (2009) emphasise multilateral organisations as an arena that catalyses the power of intermediate States, being loci for cooperation among players with similar interests and for bargaining with Great Powers.

Lastly, the literature on regional powers addresses the interaction of this structural limitation in geographical terms. This category has been the main expression of the intermediate position in realist perspectives, as it defines a scope mediating the systemic distribution of coercive capacities. Regional powers are seen as actors which, despite not determining the systemic polarity and not projecting power globally, do it regionally and, by doing so, become necessary to understanding the system (Nolte 2010: 883). Buzan 
and Waever (2003: 50-6) consider that the end of bipolarity removed the overlay of systemic securitisation, and that it has been increasingly difficult to project the use of force worldwide, making regional spaces the environment where the security dilemma is most pungently manifested to the majority of states. Mearsheimer (2001: 234-8) generalises this restriction as a consequence of the 'stopping power of water' (2001: 114-28), which makes the dispute for regional hegemony determine the polarity and polarisation of the system. Whereas rise in this literature, mainly connected with security studies, is related to amplifying the scope of force projection or the conditions to determine systemic polarity, part of the literature stresses the relevance of more plural regional dynamics on this path.

Buzan and Waever (2003) conceive regional polarisation, its patterns of amity and enmity, as a complex societal phenomenon. Leadership and authority are perceived as central components in this sense (Flemes 2007; 2010; Nolte 2010; Destradi 2010; Frazier and Stewart-Ingersoll 2013). Hence, a diplomatic claim for regional leadership must be grounded in the possession of will and resources to provide public goods and act as the stabiliser of the subsystem, but also in being recognised for this role (Mattli 1999; Flemes 2007; 2010; Schirm 2010; Wehner 2014). Pedersen (2002) conceives this social element of the path to leadership as a cooperative hegemony, in which the benefits from cooperation - i.e. material gains and stability - exceed the costs related to the acceptance of the authority. Nolte (2010: 895) stresses the asymmetry of such cooperation once the magnitude of the gains made by the cooperative leader is greater than those obtained by other members. Gilpin (2000; 2001: 361) highlights the relevance of economic regionalisation as a necessary strategy for states and economic groups within it to be able to thrive globally in the oligopoly environment of globalisation.

Altogether this literature provides three conceptions of the intermediate position, of the content that characterises it, and provides its internal logics. In distinctive ways, by observing what gives sense to the particularity of intermediate states, these categories reveal the limits of their own existence within its own logics. In this sense, the convention on the rupture with stasis of the intermediate position is manifested in three dimensions. The semi-periphery discusses it as an organic feature of world capitalism, possessing longue dureé determinants and from which the rise of a particular state is due to a very particular situation. The other two categories discuss the positional consequences of that as a structural constraint, but also as its behavioural consequences. Middle power literature focuses on how their limits of hard power make it reasonable to search for greater influence in the system by engaging in international institutions through coalition building. Recent work on regional powers stresses that intermediate states have a geographical range in their influence, in which threats, leadership, historical identities, interstate cooperation, and economic integration have augmented relevance and particularly affect the role those countries can play in world affairs.

In order to fill the theoretical gaps of their time, that literature on intermediate states stresses the position itself, the conundrum deriving its static manifestation and its continuity rather than its disruptive dynamic. However, the course of systemic change in recent years has responded to this with the spread of narratives of change incorporated into the discipline through the term emerging power. The dialogue between these theories of 
continuity and those narratives of change from the intermediate position in international politics is seen as one that constitutes the substantive content of the concept of an emerging power in international relations.

\section{Final remarks: transience and stasis in the duality concept of an emerging power in international relations}

As stated before, the concept of emerging power arises as a semantic manifestation of the historical process of economic and political transformations in international relations observed in this century, highlighting the empowerment of former emerging markets. The gain of space these players have observed in the world economy opened a conceptual blank in the discipline's theoretical framework to comprehend such a phenomenon. The adjective emerging transformed its meaning derived from the financial literature, in which the change of its referents has been narrated through the label emerging power, conducting it to a renewed place in international relations vocabulary.

In this narrative of change, such a greater economic growth in the developing world has empowered its major players to make a claim for space in global governance, by either reforming or revising status quo order (Hurrell 2006; Tammem 2006; Cooper, Antikiewicz and Shaw 2007; Ikenberry 2008; 2011; Chin 2010; Schirm 2010; Narlikar 2013; Kahler 2013; Gray and Murphy 2013; Stephen 2014; Chin 2014; Cooper and Farooq 2015). Their ambitions are conceived as being related to their particular trajectory of exclusion, attaching their behaviour to an ideological foundation or identity connected with their common historical origin in the Global South or the Third World (Palat 2008; Callahan 2008; Nel 2010; Santos 2011; Hurrell and Segupta 2012; Hurrell 2013). These attributes defy the theoretically stagnant conception of intermediate states, shedding light onto narratives of change.

At the same time that these narratives tell a story of transience and give sense to a historical momentum - the empowerment of the Global South - they also posit a challenge to international relations theory that goes beyond the historical circumstances the concept was originally reflecting. Although the increasing entropy governing the current 'age of disorder' makes the change depicted in this narrative much less linear (Schweller $2011 ; 2014)$, the semantic challenge it conveys to the discipline remains patent. In other words, as the rise of the concept of emerging power bequeaths to the discipline a theoretical demand to understand how stratification - such as the North and South cleavage - is broken, the increasing challenges that this concrete experience of emergence faces makes it necessary to cope with the question of what makes that stratification endure (Lees 2012). For instance, part of the literature employing the term is already facing the issue through this path (Sharma 2012; Chin 2014; Fernandes, Garcia and Cruz 2015). Therefore, to consolidate itself as an analytical key of international relations theory, the concept emerging power has to break its own synchronic logic of describing a historical juncture. It must engage in a progressively closer dialogue with the pragmatic knowledge 
about the object it connotes - stratification of the international system - which reveals its disruptive dynamic through its opposite - the conceptions of rise of intermediate states.

The confrontation of conceptions of rise associated with the experience of emerging powers nowadays and those established in the theory of international relations aims to outline a route to understanding the transformation the rising powers inflict on international affairs by contextualising its episodic manifestation with the endowed conceptions on the regularity of the phenomena that history is now describing. The opposition within the concept of emerging power allows for outlining at three synthetic dimensions that are presented here to guide this dialogue between change and continuity. Firstly, the rise of intermediate states has to address its materialistic foundation, the disruptive change in the conjunction of transactions that make up a country's position in the world economy and enables its political influence. This aspect raises the question of the effective structural character of the empowerment acquired by some states denoted as emerging powers. Secondly, these countries' management of those inequalities in the international order makes it relevant to understanding their strategy of leadership in international institutions regarding how they affect normative structures and whether they achieve a rule-making role in different international regimes. In this sense, this dimension permits theory to face the contingency of praxis, addressing the real potentialities of a 'meta-power' ${ }^{14}$ from multilateral activism as an effective strategy for non-establishment and historically excluded actors. Thirdly, the connections between regional and global dynamics seems inherent to the comprehension of the conditions of rising for emerging powers. Thus, the search for global influence has to deal with a greater concentration both of potential sources of threats and of stronger cooperation within the regional realm.

In conclusion, this duality between particularity and regularity, transience and stasis, change and continuity comprising the concept's formation reveals three aspects that seem to deserve further debate regarding the constitutive analytical character of the phenomenon of emerging power in international relations. The concept, in this sense, portrays a reality that instigates theorisation on the intermediate position to face the effective determinants of its change and, at same time, it states the limits of such possible change. Therefore, this work is intended to present this constitutive analysis of the concept of an emerging power as a necessary route to properly understanding its role as an analytical tool within the discipline.

\section{Notes}

1 Examples of such initiatives are: the Centre for Rising Powers at the University of Cambridge; the Rising Powers Initiative at George Washington University, the BRICLab at Columbia University, and the BRICS Center at the University of Toronto.

2 Refering to the terms of Sartori (1970: 38). 'Conceptual travelling' is the qualification of new referents throughout space and time, the amplification of the concept's extension. 'Conceptual stretching' is the connototive distortion that derives from the attempt to fit these new cases by widening its intension. This illustrative reprentation is atributed by Hurrell (2000: 3) to a German diplomat in the post-war period.

4 Sartori (1970: 1041) identifies extension as the number of referents in a given category and intension as the set of attributes that determine the membership of this category. Both make up what the author calls 
the 'ladder of generality' of a concept. An over-extension occurs when a concept is deformed to embrace new cases. To better understand the evolution of this discussion, see Sartori (1970; 1984: 52-3), Collier and Mahon (1993), and Goertz (cited in Collier and Gerring 2009).

5 Resources taken in the short term, in low interest rate markets, to be invested in higher risk and return operations, in this case, securities denominated in non-convertible currencies of emerging countries (Cintra 2005; Levi 2009; Pilbeam 2013).

6 Visentini (2013) traces the term emerging power back to debate on the rise of contenders to British hegemony in the late nineteenth centurey. Paul Kennedy's (1989) comprehensive research sought to understand the overall paterns guiding the rise of new great powers. Waltz (1993) revives the term emerging power to identify Japan and Germany as the potential rivals of American fleeting unipolarity. The idea of a rising power is also familiar in literature on power transition and on war and change in international relations. However, those concepts usually refer to dispute of power among first-tiers of internation politics, in contrast with the current meaning attributed to contemporary emerging powers.

7 The reference to these terms has been searched in fulltexts with boolean search throughout fifteen academic databases: 1) Academic Search Premier - EBSCO; 2) Gale - Academic One File; 3) Cambridge Journals Online; 4) Duke University; 5) JSTOR; 6) Project Muse; 7) political science area of Qualis CAPES/Brasil; 8) CAPES/Brasil database for doctoral dissertations; 9) Sage; 10) Oxford University Press for Social Sciences; 11) Google Academic; 12) SCOPUS for Social Sciences; 13) Scielo Brasil; 14) Web of Science; and 15) Wiley and Sons Online.

8 Those previously stated in the footnote 6 .

9 The analysed texts were all those that employed the terms emerging market, emerging country, emerging power or rising power in their title or abstract in the area of international relations of JSTOR reviews or in A1 or A2 reviews in the Qualis-CAPES system, plus additional referential corpus. The semantical study consisted of family resemblance analysis, which means the search of common qualifations or defintions attributed to the adjectives analysed. The semantic patterns that derive this network of analogous meanings were translated into the text that comprises this section.

10 Translated from Portuguese.

11 Economic Commission of Latin America and the Caribbean of United Nations, created in 1948.

12 Here the concept of World-System in terms of Wallerstein (1974) is adopted, in lieu of Braudel's (1985) concept of World-Economy. The option relies on the reasoning exposed by Braudel himself (1985), about the necessarily universal character of the first and spatially delimited of the second.

13 Nominally, the case of Japan and China (Arrighi 1994; 2007).

14 In reference to Krasner's (1985: 13-5) conception of 'meta-power' as the influence a country acquires by changing the rules of the game according to its preferences. It is worth mentioning that it would also mean for the country to be closer to having what Suzan Strange (1989) has called structural power, as capacity to influence the environment in which others' interactions occur, in contrast with relational power, which emerges directly from a specific interaction in a Dahlnian sense.

\section{References}

Andreasson, Stefan. 2001. 'Africa's prospects and South Africa's leadership potential in the emerging markets century'. Third World Quarterly, 32 (6): 1165-81.

Arrighi, Giovanni. 1990. 'The Developmentalist Illusion: A Reconceptualization of the Semiperiphery.' In William G. Martin (eds). Semiperipheral States in the World-Economy, pp. 11-41. New York: Greenwood.

1994. The Long Twentieth Century: Money, Power and the Origins of Our Times. London:

Verso.

2007. Adam Smith in Beijing: lineages of the twenty-first century. London: Verso. 
Barros-Platiau, Ana Flávia. 2010. 'When emerging countries reform global governance of climate change'. Revista Brasileira de Política Internacional, 53: 73-90.

Beeson, Mark and Stephen Bell. 2009. 'The G-20 and International Economic Governance: Hegemony, Collectivism, or Both'. Global Governance: A Review of Multilateralism and International Organizations, 15 (1): 67-86.

Braudel, Fernand. 1985. A Dinâmica do Capitalismo. Rio de Janeiro: Rocco.

Bruetsch, Christian and Mihaela Papa. 2013. 'Deconstructing the BRICS: Bargaining Coalition, Imagined Community, or Geopolitical Fad?' Chinese Journal of International Politics, 6: 299 - 327.

Burges, Sean. 2013 'Brazil as a bridge between old and new powers?' International Affairs, 89 (3): 577-94.

Buzan, Barry. 2011. 'A World Without Superpowers: Decentered Globalism'. International Relations, 25(1): 1-23.

Buzan, Barry and Ole Waever. 2003. Regions and Powers: The Structure of International Security. Cambridge, Cambridge University Press.

Callahan, William. 2008. 'Chinese Visions of World Order: Post-hegemonic or a New Hegemony?' International Studies Review, 10: 749-61.

Castañeda, Jorge. 2010. 'Not Ready for Prime Time: Why Including Emerging Powers at the Helm Would Hurt Global Governance'. Foreign Affairs, 89 (5): 109-22.

Chin, Gregory. 2010. 'Remaking the architecture: the emerging powers, self-insuring and regional insulation'. International Affairs, 86(3): 693-715.

2014. 'The BRICS-led Development Bank: Purpose and Politics beyond the G20' Global Policy, 5(3): 363-76.

Cooper, Andrew and Asif Farooq. 2015. 'Testing the club culture of the BRICS: the evolution of a New Development Bank.' Contexto Internacional, 37(1): 13-56.

Cintra, Marco Antônio. 2006 'A Exuberante Liquidez Global'. Economia Política Internacional: Análise Estratégica, 5: 17-26.

Cooper, Andrew, Agata Antikiewicz and Timothy Shaw. 2007. 'Economic Size Trumps All Else? Lessons from BRICSAM'. International Studies Review, 9: 673-89.

Cooper, Andrew and Daniel Flemes. 2013. 'Foreign Policy Strategies of Emerging Powers in a Multipolar World: an introductory review'. Third World Quarterly, 34 (6): 943-62.

Claudín, Carmen. 2011. ‘QQué Rusia veinte años después?’ Revista CIDOB d’afers internacionals, 96: 11-23.

Collier, David and James Mahon. 1993. 'Conceptual "Stretching” Revisited: Adapting Categories in Comparative Studies.' American Political Science Review, 87(4): 845-55.

Collier, David and Stephen Levitsky. 1997. 'Democracy with Adjectives: Conceptual Innovation in Comparative Research'. World Politics, 49(3): 430-51.

Cox, Robert. 1989. 'Middlepowermanship, Japan, and Future World Order'. International Journal, 44: 823-62.

Destradi, Sandra. 2010 'Regional powers and their strategies: empire, hegemony and leadership'. Review of International Studies, 36(4): 903-30. 
Desai, Raj and James Vreeland. 2011. 'Global Governance in a Multipolar World: The Case for Regional Monetary Funds'. International Studies Review, 13: 109-21.

Fernandes, Luis, Ana Garcia and Paula Cruz. 2015. 'Desenvolvimento desigual na era do conhecimento: a participação dos BRICS na produção científica e tecnológica mundial.' Contexto Internacional, 37(1): 215-53.

Flemes, Daniel. 2007. 'Conceptualising Regional power in International Relations: Lessons from the South African Case'. GIGA Working Papers, 53.

Flemes, Daniel (ed). 2010. Regional Leadership in the Global System: Ideas, Interests and Strategies of Regional powers. London: Ashgate.

. 2013. 'Network Powers: strategies of change in the multipolar system'. Third World Quarterly, 34 (6): 1016-36.

Frazier, Derrick and Robert Stewart-Ingersoll. 2013 Regional powers and Security Orders: a theoretical framework. New York: Routledge.

Gerring, John. 2001. Social Science Methodology: a criteria framework. Cambridge: Cambridge University Press.

Gilpin, Robert. 2000. The Challenge of Global Capitalism: The World Economy in the $21^{\text {st }}$ Century. New Jersey: Princeton Paperbacks.

2001. Global International Political Economy: understanding the International Economic Order. New Jersey: Princeton Paperbacks.

Goertz, Garry. 2006. Social Science Concepts: a user's guide. Princeton: Princeton University Press. . 2009. 'Point of Departure: intension and extension.' In David Collier and John Gerring (eds). Concepts and Method in Social Science: The Tradition of Giovanni Sartori, pp. 181-203. London: Routledge.

Golub, Philip. 2013. 'From the New International Economic Order to the G20: how the 'global South' is restructuring world capitalism from within'. Third World Quarterly, 34 (6): 1000-15.

Gray, Kevin and Craig Murphy. 2013. 'Introduction: rising powers and the future of global governance.' Third World Quarterly, 34(2): 183-93.

Harvey, Campbell. 1995a. 'Predictable Risk and Returns in Emerging Markets.' Review of Financial Studies, 8: 773-816.

. 1995b. 'The Risk Exposure of Emerging Equity Markets.' World Bank Economic Review, 9(1): 19-50.

Holmes, John. 1984. 'Most Safe in the Middle', International Journal, 39(2): 367-88.

Hurrell, Andrew. 2006. 'Hegemony, liberalism and global order: what space for would-be great powers?' International Affairs, 82(1): 1-19.

. 2013. 'Narratives of emergence: Rising powers and the end of the Third World?' Brazilian Journal of Political Economy, 33(2): 203-21.

2000. 'Some Reflections on the Role of Intermediate Powers in International Institutions'. In Andrew Hurrell et al. (eds.) Paths to Power: Foreign Policy Strategies of Intermediate States, pp. 1-11. Washington: Woodrow Wilson Centre for Scholars.

Hurrell, Andrew and Sandip Segupta. 2012. 'Emerging powers, North-South relations and global climate politics.' International Affairs, 88(3): 463-84. 
International Monetary Fund. 2015. World Economic Outlook, April. Washington, DC.

Ikenberry, Gilford John. 2008. 'The Rise of China and Future of the West.' Foreign Affairs, 87(1): 23-37.

2011. 'The Future of Liberal World Order'. Foreign Affairs, 90(3): 56-62.

Ikenberry, Gilford John, Michael Mastanduno and William C Wohlforth (eds). 2011. International Relations Theory and the Consequences of Unipolarity. Cambridge: Cambridge University Press.

Jordaan, Eduard. 2003. 'The Concept of a Middle power in International Relations: Distinguishing between Emerging and Traditional Middle powers'. Politikon: South African Journal of Political Studies, 30(2): 165-81.

Kahler, Miles. 2013. 'Rising powers and global governance: negotiating change in a resilient status quo.' International Affairs, 89(3): 711-29.

Kang, David C. 2007. China Rising: peace, power and order in East Asia. New York: Columbia University Press.

Keohane, Robert. 1969. 'Lilliputian's Dilemmas: Small States in International Politics', International Organization, 23(2): 291-310.

Khanna, Parag. 2008. O Segundo Mundo. Rio de Janeiro: Intrínseca.

Kose, M Ayhan. 2008. 'Seven Questions About Decoupling'. IMF Research Bulletin, 9(3).

Krasner, Stephen. 1985. Structural Conflict: The Third World against Global Liberalism. Berkeley: University of California Press.

Koselleck, Reinhart. 2004. Future Past: On Semantics of Historical Time. New York: Columbia University Press.

Lakoff, George. 1990. Women, fire and dangerous things: what categories reveals about the mind. Chicago: University of Chicago Press.

Layne, Christopher. 2009. 'The Waning of U.S. Hegemony: Myth or Reality'. International Security, 34(1): 147-72.

2012. 'This Time it's Real: the end of unipolarity and the pax Americana.' International Studies Quarterly, 6: 203-13.

Lees, Nicholas. 2012. 'The dimensions of the divide: vertical differentiation, international inequality and North-South stratification in international relations theory.' Cambridge Journal of International Affairs 25 (2): 209-30.

Levi, Maurice D. 2009. International Finance. London: Routledge.

Lima, Maria Regina Soares de. 1990 'A Economia Política da Política Externa Brasileira: Uma Proposta de Análise.' Contexto Internacional, 12: 7-28.

MacFarlane, Neil. 2006. 'The " $\mathrm{R}$ ” in BRICs: is Russia an emerging power?' International Affairs, 82 (1): 41-57.

Mattli, Walter. 1999. The Logic of Regional Integration: Europe and Beyond. Cambridge: Cambridge University Press.

Mattoo, Aaditya and Arvinda Subramanian. 2009. 'From Doha to the Next Bretton Woods: A New Multilateral Trade Agenda'. Foreign Affairs, 88(1): 15-26.

Mearsheimer, John. 2001. Tragedy of Great Powers Politics. London/New York: Norton. 
Narlikar, Amrita. 2010. New Powers: How to become one and how to manage them. London/New York: Hurst Publications/Oxford University Press.

. 2013. 'Negotiating the rise of new powers'. International Affairs, 89 (3): 561-76.

Nel, Philip. 2010. 'Redistribution and recognition: what emerging regional powers want'. Review of International Studies, 36: 951-74.

Nolte, Detlef. 2010. 'How to compare regional powers: analytical concepts and research topics.' Review of International Studies, 36 (4): 881-901.

O’Neill, Jim. 2001. 'Building Better Global Economic BRICs.' Goldman Sachs Global Economics Paper, 66.

. 2003. 'Dreaming With BRICs: Path to 2050'. Goldman Sachs Global Economics Paper, 99. 2007. BRICs and Beyond. New York: Goldman Sachs.

O’Neill, Jim, Dominic Wilson, Roopa Purushothaman and Anna Stupnytska. 2005. 'How Solid are the BRICs?' Goldman Sachs Global Economics Paper, 134.

Palat, Ravi. 2008. 'A new Bandung? Economic growth vs. distributive justice among emerging powers. Futures, 40(8): 721-34.

Patrick, Stewart. 2010. 'Irresponsible Stakeholders? The Difficulty of Integrating Rising Powers'. Foreign Affairs, 89 (6): 44-53.

Pedersen, Thomas. 2002. 'Cooperative hegemony: power, ideas and institutions in regional integration'. Review of International Studies, 28 (4): 677-96.

Pereiro, Luis. 2002. Valuation of companies in emerging markets - a practical approach. New York: Wiley.

Pilbeam, Keith. 2013. International Finance. London: Palgrave Macmillan.

Rosch, Eleanor and Carolyn Mervis. 1975 'Family Resemblance: Studies in the Internal Structure of Categories'. Cognitive Psychology, 7: 579-605.

Santos, Theotonio. 2011. 'Globalization, Emerging Powers, and the Future of Capitalism' Latin American Perspectives, 38: 45-57.

Sartori, Giovanni. 1970. 'Concept Misformation in Comparative Politics'. American Political Science Review, 64: 1033-53.

Sennes, Ricardo. 2003. As mudanças da política externa brasileira nos anos 80: uma Potência Média recém industrializada. Porto Alegre: UFRGS.

Sharma, Ruchir. 2012. 'Broken BRICs: Why the Rest Stopped Rising.' Foreign Affairs, 91 (6). Available in: https://www.foreignaffairs.com/articles/brazil/2012-10-22/broken-brics.

Schenoni, Luis Leandro. 2012. 'Ascenso y hegemonía: pensando a las potências emerginges desde América del Sur'. Revista Brasileira de Política Internacional, 55(1): 31-48.

Schirm, Stefan. 2010. 'Leaders in need of followers: emerging powers in global governance' European Journal of International Relations, 16: 197-221.

Schweller, Randall. 2011. 'Emerging Powers in an Age of Disorder'. Global Governance, 17: 285-97.

2014. 'The Age of Entropy'. Foreign Affairs, 92 (3). Available in: https://www.foreignaffairs.com/articles/united-states/2014-06-16/age-entropy.

Schwengel, Hermann. 2008. 'Emerging powers as fact and metaphor: some European ideas'. Futures, 40(8): 767-76. 
Solnik, Bruno. 1991. International Investments. New York: Addison Wesley.

Stuenkel, Oliver. 'Identidade, status e instituições internacionais: o caso do Brasil, da Índia e do tratado de não proliferação'. Contexto Internacional, 32 (2): 519-61.

Stephen, Matthew. 2014. 'Rising powers, global capitalism and liberal global governance: A historical materialist account of the BRICs challenge.' European Journal of International Relations, 21: 1-27.

Strange, Susan. 1989. States and Markets. New York: Continuum.

Tammen, Ronald. 2006. 'The Impact of Asia on World Politics: China and India Options for the United States'. International Studies Review, 8(1): 563-80.

Thakur, Ramesh. 2014. 'How Representative are the BRICS?' Third World Quarterly, 35(1); 1791-808.

Vanaik, Achin. 2014. 'Capitalist Globalisation and the Problem of Stability: enter the new quintet and other emerging powers.' Third World Quarterly, 34(2): 194-213.

Visentini, Paulo. 2013. BRICS: As potências emergentes. São Paulo: Vozes.

Wallerstein, Immanuel. 1974. The Modern World-System: Capitalist Agriculture and the Origins of the European World-Economy in the Sixteenth Century. New York: Academic Press.

. 1976. Semi-Peripheral Countries and the Contemporary World Crisis. New York: Aca-

demic Press.

Wehner, Leslie. 2014. 'Role expectation as foreign policy: South American secondary powers' expectation of Brazil as a regional power'. Foreign Policy Analysis, 0: 1-21.

Weinlich, Silke. 2014. 'Emerging powers at the UN: ducking for cover?' Third World Quarterly, 35(1), 1829-44.

Wittgenstein, Ludwig. 2009. Philosophical Investigations. Oxford: Backwell.

World Bank. 2013. World Development Report 2013. Washington, DC.

\section{Acknowledgements}

The authors would like to thank the Editors of Contexto Internacional and the anonymous reviewers for their insightful comments and sugestions, and for the thorough revision.

\section{About the authors}

Lucas de Oliveira Paes is a $\mathrm{PhD}$ candidate at the Josef Korbel School of International Studies, University of Denver, USA. He holds a Master's degree in International Strategic Studies, and a Bachelor's degree in International Relations, both from the Federal University of Rio Grande do Sul (UFRGS), Brazil. His research interests include the conceptual debate on the rise of new powers from Global South, and the effects of power transition dynamics on foreign policy. On a theoretical level, he is engaged in the renewed issue of structural and relational approaches to macro-level dynamics of international politics, specifically the use of the intersection between structural differentiation framework and network analysis to address constraints and opportunities for emerging powers form Global South. 
André Moreira Cunha is Associate Professor of Economics and International Relations at the Federal University of Rio Grande do Sul (UFRGS). He holds both a Masters's and a Doctoral degree in Economics from the University of Campinas (UNICAMP), Brazil. $\mathrm{He}$ is Research Fellow in Economics at CNPq, Brazil, and former Visiting Scholar at Cambridge University, United Kingdom (2011/2012), and at Leiden University, Netherlands (2006). His research interests include the macroeconomic aspects of international trade and finance, globalisation, economic integration, and their effects on policy options in the periphery of the world economy. His work has been published in the Brazilian Journal of Political Economy, Cepal Review, Latin America Research Review, Journal of Post Keynesian Economics, America Latina Hoy, among others.

Pedro Cezar Dutra Fonseca is Professor of Economics and International Relations at the Federal University of Rio Grande do Sul (UFRGS), Brazil. He holds both a Bachelor's and a Master's degree in Economics from the same institution, and a $\mathrm{PhD}$ in Economics from the University of São Paulo (USP), Brazil. He is Senior Research Fellow in Economics at $\mathrm{CNPq}$, and a full member of its Economics Committee. His research interests are on economic development, Brazilian economic history in the 20th century, and history of economic thought. He is currently a member of the board of directors at the Celso Furtado International Center, and Director of the Center for International Studies on Government at the UFRGS, Brazil.

Received on 20 May 2016, and approved for publication on 11 October 2016.

\section{(cc) BY-NC} https://creativecommons.org/licenses/by-nc/4.0/ 
